Culture, Personality and Education

МәАәният, шәхес һәм мәгарифр

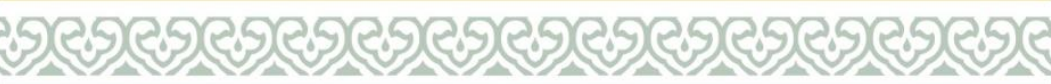

Культура, Аичность и образование

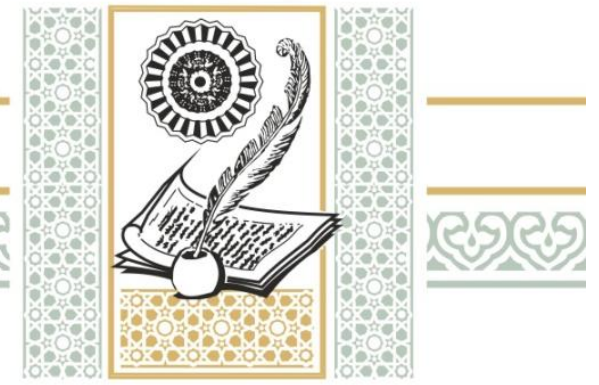

DOI: $10.26907 / 2311-2042-2021-16-1-127-141$

\title{
THE UNKNOWN PAGES IN THE BIOGRAPHY OF NAKI ISANBET
}

\author{
Granit Nurullovich Zinurov, \\ Office 206, Bldg. 1, 37 K. Marx Str., Ufa, 450000, Russian Federation, \\ abzalimovarg@mail.ru.
}

\begin{abstract}
The article fills in "blank spots" in the biography of the great Tatar writer, folklorist, scholarencyclopedist Naki Isanbet (1899-1992), a native of Bashkortostan. Our study is based on local history and archival materials as well as fictional and folklore texts of the writer. The purpose of the work is to identify the significance of the Lakly village page in Naki Isanbet's biography in order to understand the features of his worldview and the meaning of his activity as an enlightener.
\end{abstract}

Key words: Tatar literature, Tatars, history of Bashkortostan, Lakly, mullah.

\section{Introduction}

The study of the writer's life path is one of those problems that have always aroused great interest among literary critics, teachers and local historians. This is quite natural, because, as the methodist V. G. Marantzman correctly noted, "the life of an artist is no less exciting and instructive than the fate of the characters he creates" [Marantzman, p. 38]. According to E. N. Kolokoltsev, the biography of the word artist is not a set of separate, isolated facts of their life and work. Their biography is "the personified time", "the spiritual evolution of the writer and its material expression, the emergence of creative stimuli at various stages of life" [Aktivnye formy prepodavaniia literatury, p. 54]. It is well known, that to understand writers' artistic world we should study their biography.

There are many "blank spots" in the biography of the great writer-encyclopedist Naki Isanbet (1899-1992). Unfortunately, the monographs and biographical articles about the great scientist provide insufficient information on the period of his life spent in the territory of the present Republic of Bashkortostan ([Shamukov], [Khanzafarov], [Adip ham galim], [Khabutdinov, Khabutdinova], [Khabetdinova], [Khabutdinova]). The purpose of this article is to deepen our understanding of $\mathrm{N}$. Isanbet's genealogy, the Lakly village period of his life path for a wide range of readers. Our study is based on local history materials and the works of the writer himself.

\section{Methods}

We used the method of semantic analysis, as well as the historical and cultural methods to study the literary texts.

\section{Discussion}

The village of Lakly is located on the northeastern outskirts of the Republic of Bashkortostan. 
There are different versions of the name origin of this village in the Salavat district: "lakly", "ulak" among the local residents. Turkic-speaking peoples denote the constellation of Capricorn with these words. Local residents talk about the herds of wild goats that used to live in the mountains, surrounding the village. The name of the village might be connected with these circumstances. It is known that the German scientist-encyclopedist, naturalist and traveler Peter Simon Pallas, who worked in Russia in 1767-1810, visited Lakly. It happened on May 25, 1770 (10 years after coming to these lands): "I went to see the memorable cave, three versts from the road to the Tatar village of Tsigyartsinkul. Its inhabitants, according to the general custom formerly existing in this country, paid an old yasak to the treasury (toll - G. Z.) or marten furs for the same price. This village, consisting of a few houses, lies at the Lyakle Zilge stream, which flows into the Ai River. This stream is the border of the fertile plain where Zalikhaul is situated (i.e. Nasibash)" [Pallas, p. 68]. The village may have got its name from the name of the stream -- Lyakle Zilge.

The famous Tatar writer-encyclopedist Naki Isanbet (1899-1992) uses the name Ylakly in his works. The name of the village is found in the collections of riddles and proverbs, compiled by the folklorist. The collection "Tatar halyk tabyshmaklary" ("Tatar Folk Riddles") contains several riddles, recorded in the village of our ancestors. Here, for example, is the riddle of water:

\begin{tabular}{|l|l|}
\hline "Үзе тигез, Үзе такыр, & "It is smooth, it is even, \\
Бассаң - батар. & You step on it and you \\
Исе юк, төсе юк, & sink. \\
Аннан башка тормыш & No smell, no color, \\
юк" & Without it, life is \\
[Исәнбәт, 1970, б. 116]. & impossible" [Isanbet, 1970, \\
(here and further translated & p. 116]. \\
by the author- G. Z.) & (here and further translated \\
& by Khabutdinov A.Iu.) \\
\hline
\end{tabular}

The riddle of the cow's horn:

\begin{tabular}{|l|l|}
\hline "Коры ботакка кайгыр & "A small, nimble hawk \\
кунмас.." [Шунда ук, б. & will not sit on a dry \\
225]. & branch" \\
& [Ibid., p. 22] \\
\hline
\end{tabular}

In the collection "Tatar halyk makallare" ("Tatar Folk Proverbs"), we found a number of proverbs recorded in our village: "Yunsez itegen mylar, / Itege itegen mylar' ("The stupid will lubricate the boots, and the boots will lubricate the hem of the dress") [Isanbet, 2010, p. 231], "Isapkahisap, / Kilega-kisap". ("Account makes calculation, a mortar makes a pestle") [Ibid., p. 259], "Uralnyn uravy kup" ("There are many routes around in the Urals") [Ibid., p. 307], "Altyn yukta jizne, 'jiz myek jizni' deep yor'terlar, imesh" ("They say that a son-in-law who does not have gold is called 'a son-in-law with a brass mustache"”) [Ibid., p. 310], etc.

Naki Isanbet, a native of the Tatar village of Malayaz in the Ufa Province (now the Republic of Bashkortostan), mentions the village of Ylakly in his works, in particular, in the adventure book written for children, "Bereze Pesie Myraubai batyr majaralary" ("The Adventures of Myraubai Batyr, the Cat from the Village of Bereze"). In the 8th adventure of the Myraubai cat, we read that the inhabitants of a number of Tatar localities report that they learned too late about the Jiyen (convention) in the Arsky field of Kazan:

\begin{tabular}{|l|l|}
\hline «Соң ишеткән бу хәбәрне & “The residents of Kolatka \\
Колаткылар, & learned too late about this \\
Алабуга, Богадышлар, & news, \\
Ылаклылар, & As well as the residents of \\
Атау, Кыйгы, Яңа & Alabuga, Bogadysh, Lakly, \\
Мөслим, Өлкенделәр: & Atau, Kyigy, Yana Mus- \\
- Ах, ник алдан & lim, Ulkindi: \\
белмәдек! - дип & - Ah, why didn't we know \\
үкенделәр» & about it! they kept griev- \\
[Исәнбәт, 1974, б. 64]. & ing” \\
& [Isanbet, 1974, p. 64]. \\
\hline
\end{tabular}

In the author's notes, Naki Isanbet explains the phenomenon of these villages: "Ylakly, Atau, Kyigy, Yana Muslim, Ulkindi - Bashkortostan Salavat raionyndagi zur Tatar avillary. Bolardan zur galimnar, shagyyrlar da chykkannar" [Isanbet, Bereze pesie..., p. 64]. - "Lakly, Atau, Kigi, Yana Muslim, Ulkindi are large Tatar villages in the Salavat district of Bashkortostan. Famous scientists, as well as poets came from there.

$\mathrm{N}$. Isanbet's comment is true. If you turn to the archival documents, you can find out that the village of Lakly in the present Salavat district of the Republic of Bashkortostan arose in the middle of the $18^{\text {th }}$ century according to the agreement of February 3,1760 , with the patrimony of the Tarnakly volost of the Orenburg province. It was founded by seven householders who separated from the village of Taymeyevo and settled on the bank of the Ai River, at the mouth of the Lakly River. Among the first settlers was mullah (imam) Suleymanov Gaisa (1729-1802). The first mosque in the village was built with his blessing. Gaisa mulla led the first Lakly mahalla (parish) for over four decades. Ac- 
cording to family traditions, Gaisa, like his father, received a spiritual education in Bakhchysarai (Crimea). Later, in 1798, the administration of the Lakly parish was passed into the hands of his eldest son Khudaibirde (1768-1847) (Decree of Ufa Provincial Government No. 12623 of May 3, 1811). Isiyadulla Seifullin received the position of azancha (muezzin) of this parish at the same time. The Decree notes that Khudaibirde (G) Aisin was a native of the Teptyar estate.

A treaty was issued on the relocation of Lakly residents from the village of Taymeyevo in 1760. It was a sensational discovery for us. If you translate this document, written in Tatar with Arabic script into Russian, it reads:

"This is a historical decision written in the Tatar language with the consent of (the people mentioned below) in the year one thousand seven hundred and sixty at the beginning of the month of Shawal on the third day of it, (we) give:

We, the Ufa district, the Siberian road, the Tarnakli troop (volost) people, old and young, with our common consent, give the land, given to us by the Decree of the Merciful Padishah the Great Hazret (His Imperial Majesty), we ceded to the same Ufa district, the Siberian Road to the village of Atav to the yasak Tatars: Yaguda - the son of Alka, his elder brother mullah Khalil -- the son of Alka, mullah Gaisa -- the son of Suleiman, Ismagil -- the son of Sait, Ibrai -- the son of Nurka, centurion Maksut -- the son of Gabdulla, Gumer -- the son of Utegan with suitable companions. [We gave the land] to ten landlords from the owner to the owner with a payment of twenty-five kopecks, the son to the son, the blood of blood forever passes. If the son is separated from the father, if the younger brother is separated from the older brother and there are more houses than indicated above, they also decided to take twenty-five kopecks from the yard" [Natsional'nyi arkhiv Respubliki Bashkortostan. F.I-10, op.1, d.1495, p. 9].

According to this agreement, about 6,000 desyatins (16.198 acres) of land were allocated to the Lakly people, who came from from Taymeyevo.

The archival materials indicate that there was a simple mosque in Lakly. It functioned only on Fridays, due to the lack of parishioners. According to the laws of that time, a minimum of 200 male parishioners were required to organize a cathedral (juma) mosque. In Lakly village, there were no more than 88 male souls according to the census of 1811-1812. The Lakly people dreamed of building a large, beautiful cathedral mosque. Khudaibirde was a man of strong character. Under the pretext that the dilapidated mosque had fallen into disrepair, in 1814, together with his relatives, he dismantled it. A new building took fourteen years to be built. The dispute over the new mosque lasted until 1823 as the construction was carried out without obtaining permission from the province authorities and the Orenburg Mohammedan Spiritual Assembly (OMDS) [Natsional'nyi arkhiv Respubliki Bashkortostan. F. I-295, op. 4, d. 334 p. 9].

According to the Decree of the Ufa Provincial Government (No. 5153 of February 23, 1833), the grandson of Gaisa hazret - Bagautdin, the author of the manuscript "Kitabi Bagautdin valyady Shamsivar" (1829) was appointed the second imam and mughallim (teacher) in the new cathedral mosque. He led the parish for five decades. It is known that the Lakly madrasah soon gained popularity, thanks to his leadership. In 1858, Bagautdin hazret undertook major repairs to restore the mosque. In 1862, he transferred his ancestral lands and a plot of forest to the ownership of the mosque. The border of the forest area ran from the Urmanchinskaya road along the line of the cemetery to the "Naiskosok" road on the Khutor-Tau Mountain and deep into it. This forest area is still called "Machet saklauy" ("For the preservation of the mosque"). Bagautdin hazret freed his peasants. According to the memories of old residents, in a clearing in front of the forest, the Lackly youth used to gather. During the Soviet era, in the $1960 \mathrm{~s}$, this place, associated with the memory of religious figures-enlighteners, was occupied by a pig farm.

After the death of Bagautdin hazret, the local Moslem community was headed by his son, Akhmadsafa (ibn Bagautdin ibn Shamsiwar ibn Gaisa ibn Suleiman... ibn Syundiuk...). He was a well-known Tatar religious and public figure, teacher, educator, mudarris of the "Akhmadiya" madrasah. Akhmetsafa Bagautdin was the leader of the Muslims of the Zlatoust uezd (district) in the Ufa province. He received his primary education at his father's madrasah. Akhmatsafa early showed his extraordinary abilities for education. By the age of 14, he had gained fame as a person who knew Qur'an by heart (Qur'an-hafiz) and showed profound knowledge of the Qur'anic sciences and Islamic divine law -- Sharia. In 1875-1881, Akhmatsafa Bagautdin studied at the madrasah of the first mosque in the city of Troitsk, and in the summer time, he taught Kazakh children to read and write. After successful graduation from the madrasa, he served as a clerk and interpreter for the Siberian department for two years. After being elected mullah by the Lakly parish in 1883 (Janu- 
ary 19, Protocol No. 2687), on the recommendation of Bagautdin Hazret, Ahmet-Safa performed the Hajj, visited holy places for a year, purchased books, met with famous theologians of the East and received their blessings. It is known, that Akhmatsafa performed the Hajj twice. In 1884, he received Decree of Ufa Provincial Government No. 672 of February 10 on the Lakly parish as Imam, Jamig (head of the cathedral mosque), Khatib (a right to preach a sermon) and Mudarris in place of his father.

Akhmatsafa Bagautdin headed the Lakly madrasah in 1884, in the same year as Zainulla Rasulev, who headed the Rasuliya madrasah at the $5^{\text {th }}$ parish of the city of Troitsk. It is known, that ishan Zainulla visited the Lakly madrasah many times. The mullahs-educators mutually adjusted the training programs in their madrasahs.

Akhmadsafa akhun was a trustee and mudarris (director) of the Lakly madrasah "Akhmadiya", later named after him, and a teacher of the Lakly Russian-Tatar School. He actively participated in the opening of Russian-Tatar schools for boys (1894) and for girls (1905). Akhmatsafa khazret taught the native language and religion at the Russian-Tatar school. In the document on the opening of the school we read: "The Russian-Tatar school in the village of Lakly, which immediately enrolled 27 students, provides an opportunity to learn Russian literacy [to children], who before the opening (of the school) were exclusively under the influence of the Mohammedan madrasah, where more than 200 children of the Muslim population of the Zlatoust district study annually" [Arkhiv Zlatoustovskogo gorodskogo okruga]. Consequently, as early as in 1894, up to 200 children were studying at the Lakly madrasah.

In maktabs (i. e. Moslem primary school) pupils studied arithmetic, geography, astronomy, rakhbari-Sabiyan (1-3 parts), Qur'an, aftiyak, Mughallimi gibadati (1-3) parts, Gilmihal, Gibadati Islamia in the Arabic and Tatar languages, while in the Russian-Tatar school all subjects, except for the native language and Quranic disciplines, were taught in Russian.

In connection with the request of Ahmadsafa khazret and thelocal residents, the Zlatoust district Zemstvo Assembly decided to review the quality of education in the Lakly madrasah. While studying the goals and objectives of Muslim educational institutions, the Zlatoust district zemstvo board came to the conclusion that the Mohammedan educational institution-madrasah pursued general educational, spiritual and moral goals. The purpose of teaching in these schools was the same - to educate students to be literate citizens, who were useful for society and the state, to be loyal and educated people [Natsional'nyi arkhiv Respubliki Bashkortostan, arkhiv No. 1479, p. 597]. To the question of which part of Muslim villages the Lakly madrasah provided services, it was said that "the Lakly madrasah serves the entire Muslim population of the Zlatoust district" [Natsional'nyi arkhiv Respubliki Bashkortostan, arkhiv No. 546, p. 426].

In his report in 1906, the Manager of the Zlatoust district Public Education highly appreciated the activities of the famous mullah-educator: "Thanks to the ardent participation of the local mullah Bagautdinov who both opened the school in this village and attracted students to this school, 30 girls were admitted in the first year after its opening, which wss a huge success, since the Mohameddan population was very reluctant to teach Russian literacy to their children in general, and girls in particular. Noting such a sympathetic attitude of Mullah Bagautdinov to the popular education of the Mohameddan population, the Council thought that Bagautdinov's zeal should be brought to the attention of the mufti [Natsional'nyi arkhiv Respubliki Bashkortostan, F. I-295, op. 11, d. 743, p. 125].

Here is the text of the letter of the Zlatoust District Zemstvo Board to the Ufa Mufti, i. e. the chairman of Orenburg Mohammedan Spiritual Assembly in its entirety:

"Zlatoust District Zemstvo Board

November 16, 1906, No. 3538.

To His Eminence, the Mufti of Ufa.

Since the beginning of the 1905-1906 school year, the zemstvo women's Russian-Tatar primary school has been opened in the village of Lakly in the Tarnakli volost of the Zlatoust Uyezd. In view of the fact that the Bashkir population is extremely distrustful of schools opened to teach Russian literacy in general, and girls' schools in particular, the District Administration had to take very energetic steps to persuade the Lakly people to accept the named school. Moreover, the local mullah Bagautdinov, who was also a religious teacher of the zemstvo men's primary school, took an active part in convincing them, he was cordial and energetic in attracting Bashkir girls to the school. Thanks to such a fervent participation of Bagautdinov in teaching Russian literacy to school-age children in the village of Lakly, 30 students entered the newly opened Lakly girls' school in its first year. The Zlatoust District Zemstvo Assembly of the $22^{\text {nd }}$ regular session of 1906 , after hearing such a flattering response from the District Board about Mullah Bagautdinov's ardent participation in the dissemination of public education among the Bashkir population, authorized the District Council (resolution 
of October 5, 1906) to express sincere gratitude to Mullah Bagautdinov on behalf of the Zemstvo Assembly. At the same time, it proposed that such fruitful activities of $\mathrm{g}$ (ospodina) Bagautdinov should be brought to the attention of Mr. Mufti.

That is what the County Board considers it its duty to inform your Eminence about.

Chairman of the Board Aistovl" [Natsional'nyi arkhiv Respubliki Bashkortostan, F. I-295, op. 11, d. 743, p. 125].

Akhmatsafa Bagautdin made every effort to introduce his people to education and culture. He did his best to achieve this goal. Lakly village became the center of progressive education in the northeast of the Ufa province at the turn of the $19^{\text {th }}-20^{\text {th }}$ centuries thanks to his active position in the modernization of education. Orenburg Mohammedan Spiritual Assembly (OMDS) assigned him the duty to inspect all the mektebs and madrasahs of the Zlatoust district. During one of these trips, Akhmatsafa Bagautdin visited Sirazetdin mullah in Malayaz and performed the naming ceremony for his son Ahmet-Naki.

Thanks to the memoirs of Nigmatulla Zaynullin, we know that the city teachers Mahmud Sultangaliyev and his wife Sufiya, Halima Baytiryakova and others taught in the madrasah. Galimyan Safin returned to Lakly after graduating from the Orenburg "Khusainiya' madrasah. It is known that shakirds from Troitsk, Ufa, who had previously studied in the madrasas "Galiya', "Khusainiya" and others, studied in the Lakly madrasa. The madrasah taught the Tatar language, geography, history and mathematics. They had lessons of religion three times a week. The madrasah curriculum corresponded to the program of the $7^{\text {th }}$ grade of the modern school. Apparently, the Shakirds were driven into the rural hinterland by violent revolutionary events.

The living conditions for the shakirds of the Akhmadiya madrasah improved significantly after the construction of a new madrasah building in 1908. More than 200 people were trained here under the guidance of 9 mughallim. The eldest son of Akhmetsafa Bagautdin-Galimyan, a graduate of the Orenburg "Khusainiya" madrasah taught in Akhmadiya. Later, he headed a school at the Mursalimkino station (Bashkortostan).

In 1907, Akhmetsafa Bagautdin was appointed akhun of the Zlatoust district. He managed to find a common language with the local self-government organs. Thus, the mullah-educator received a zemstvo grant from for the construction of an educational institution in his native village. At the meeting of the Zlatoust District Zemsky Assembly, glasny (a deputy) Shchipitsin [ National Archive of the Republic of Bashkortostan, archive No. 1479, p. 597] asked to grant the mullah's request for the construction of a madrasa building, since Lakly was a "hotbed (source) of culture among the Muslim population" [Natsional'nyi arkhiv Respubliki Bashkortostan, Arkhiv No. 1479, p. 597]. This, of course, shows that Ahmadsafa Hazret was held in high esteem not only among the Muslim population, but also by the Russian self-government in the person of the Zlatoust Zemstvo board due to his active educational and public activities. Akhmadsafa's spouses Taiba abystay and Galima abystay also took an active part in the life of the village. They taught girls literacy and feminine hygiene. Taiba abystay was a midwife.

Akhmadsafa akhun was arrested in 1927 and served several months in the Mesyagutovo prison. The Bolsheviks were forced to release Akhun to avoid a riot on the territory of the Zlatoust district of the Ural region and the Mesyagutovo canton of Bashkortostan. When the mullah was in prison, his numerous students-shakirds, his fellow Muslims began to flock to Mesyagutovo with their families. People walked hundreds of kilometers to support a respected person and teacher. The streets of the village of Mesyagutovo were filled with people on foot, on horseback, and carts with their families. There were kilometer-long queues around the prison, and people waited weeks to see him andh receive his blessing. Akhmadsafa Khazret influence and popularity were immence. He was a holy man in the eyes of the common people. Like his ancestors, Ahmadsafa had the gift of clairvoyance, healing and psychotherapy. Akhmatsafa Bagautdin never recovered from his arrest, he fell ill and died in 1929 in his home. Prison and dekulakization were the reward from the authorities for his educational activity, but the people showed their respect and recognition of his merits.

Akhmadsafa lived very modestly. On his farm he had a cart, one tarantass, two working horses, one traveling horse, three cows, two calves and the purchased land of 15 desyatins. He did not have a land plot, since he was born after the census of 1859 , so he was not included into the list of census souls. He sowed: oats - 3 desyatins (8 acres), spring wheat $-1,5$ desyatins, potatoes -- 5 sotkas $(0,12$ acres). The rest of the land was leased out. He himself leased the haymaking land with a contract for 12 years. He had 6 children by different wives. 
Akhmadsafa's estate was a birch grove measuring 0.9 desyatins, about one hectare, stretching from east to west. On the eastern side, there was a house with a front entrance overlooking the street. In the middle of the grove stood a small octagonal building, which simultaneously served as a library, an office and a place of prayer for Akhmadsafa. The library was collected by Akhmadsafa's ancestors and the khazret himself. Located in a quiet birch grove of his estate, the building of the library was built in Oriental style, representing an octagonal star. Akhmadsafa must have known that octahedral symbols and stars have a very beneficial effect on human society and generally, on the human condition. He spent all his free time alone in his favorite library: studying, praying, meditating, searching for the truth. This library was used not only for religious books, but also for the works of Russian classics. In 1929, this library was lost. Akhmadsafa khazret did not have time to transfer the library to the state due to his untimely death during the rampant dekulakization

In the Soviet years, the idea of the Akhmadsafa Bagautdinov's "wealth" haunted some of the villagers. It seemed to them that after working for 46 years as the imam of a large Lakly parish, as a teacher and mudarris of a madrasah, as an inspector of Muslim public education in an entire district, and even as a merchant (his son Ahmadkhadiy), he must have accumulated a large fortune. No one could believe that the fortune of this well-known local enlightener consisted of a small house with two rooms and a kitchen.

In order to find the treasure, his house was moved 70 steps to the side. Naturally, no one found any treasure, since the treasure and contribution of Akhmadsafa Bagautdin was measured by the "Akhmadiya" madrasah and his spiritual contribution to the education of his people.

The first cathedral mosque in Lakly was thus built in 1828, the second cathedral mosque in 1900. In 1929, after the death of akhun, the mosque was transferred to the School of Peasant Youth. The mosque served as a school until 1970, after which a new Soviet school building was costructed.

In 1931, the house of Ahmadsafa Bagautdin was confiscated in favor of the "people" and turned into the building of the village council. The son of Akhmedsafa, Vasil, aged 21, was convicted as a counter-revolutionary under Article 58, Paragraph 10 of the Criminal Code of the RSFSR for associating with an alien element, that is, with his father.
After serving his sentence, after being released during the Great Patriotic War, he went to the front. The youngest son of Ahmadsafa Bagautdin, named Muhammad, was also a participant in the war. He spent a long time wandering around hospitals, trying to get back on his feet after a severe concussion. It is known that he died in the city of Chelyabinsk.

A birch grove of one hectare in size on the Akhun estate and one hectare near the mosque was cut down by the villagers of Akhmetsafa for firewood during the Great Patriotic War. Unfortunately, the grove that decorated the center of the village has not been restored until now [Zinnurov, 2015].

During our conversation, the former secretary of the Salavat district committee of the CPSU, Radil Mukhametdinov, who headed the district for seventeen years, noted that the most hardworking, cultured and educated people in the Salavat district were those from Lakly. The graduates of the Lakly madrasah became ministers, generals, scientists, engineers, doctors, teachers, school directors, party and economy workers. The Akhmadiya madrasah played a significant role in the cultural and educational development of the Muslim population in the Zlatoust Uyezd and the entire north-east of the Ufa Province. See: [Zinnurov, 2004], [Zinnurov, 2010], [Zinnurov, 2015].

In Naki Isanbet's autobiographical novel "Babi Chak" ("Childhood") we have found some valuable information about the genealogy of the great writer. In his work, N. Isanbet indicates that his maternal relatives lived in Lakly [Isanbet, 1999], [Isanbet, 2000]. It was the ancestral village of his grandmother Khadicha Bagautdinova, the sister of Akhmatsafa hazret:

"I was born in the family of Sirazetdin and Taiba. That is, those from Nasibash were relatives on their mother's side, on the side of Akhmetshah muezzin. Malayaz was a Tatar village, Nasibash was a Mishar village, and Khadicha's grandmother was from Lakly, they were Tatars". [Isanbet, 1999, p. 98]

The image of Lakly village is also found in the memoir article by $\mathrm{N}$. Isanbet "Unsigezenche eldan ber sahif" ("One Page of Life from the Year of 1918", 1967). Describing the tragic events during the hayfork uprising, the writer names the revolutionary heroes who died at the hands of hostile forces: in particular, such famous residents of Lakly as the Khammatovs [Isanbet, 1968, p. 106]. 
N. Isanbet went to Lakly more than once. In his youth, he had lessons with Akhmatsafa Bagautdin.

\section{Results}

For Naki Isabet, Lakly was a village-the birthplace of his maternal ancestors, the center of education in the north-east of Bashkortostan, as well as the place for collecting interesting and original folklore material.

\section{Conclusions}

The page, devoted to Lakly village in the biography of Naki Isanbet, allows us to better understand the worldview of this scientistenlightener. For several centuries, the ancestors of the writer were teachers, guides of knowledge and Muslim culture in the region. It is obvious that the immortal lines from the play "Abugalisina by $\mathrm{N}$. Isanbet form the life credo not only of the writer, but also of a whole family of Tatar mullahsenlighteners:

\begin{tabular}{|l|l|}
\hline “Аһ, юк, мин ни өчен & “Ah, What for have I \\
гыйлем алдым, & gained this knowledge, \\
Шул халкыма файдам & If it is not for the benefit of \\
тимәгәч? & my people? \\
Кояш булып кояш кемгә & Who needs the sun, \\
хажәт, & If it does not warm others \\
Башкаларга нурын & with its rays? \\
бирмәгәч? & No, no! Their happiness is \\
Юк, юк! Алар бәхте - & my happiness, \\
минем бәхтем, & I want my people to see \\
Телим - халкым күзе & clearly, \\
ачылсын, & They will gain strength \\
Гыйлем белән алар көчле & through knowledge. \\
булсын. & Let love and justice reign \\
Сөю, хаклык жирдә шаһ & on earth! \\
булсын! & Then they will realize their \\
Алар аңлар шунда үз & place, \\
хәлләрен, & No one will be a slave to \\
Артык кеше кешегә кол & anyone, \\
булмас, & No nation will enslave \\
Бер халыкны берсе & other nations, \\
табындырмас, & They will not rise above \\
Сәждә булмас, һичкем & others and bring anyone to \\
зур булмас” [Исәнбәт, & their knees”. \\
1989, б. 236] & [Isanbet, 1989, p. 236] \\
\hline
\end{tabular}

\section{References}

Adip ham Galim (1969) [A Writer and a Scientist]. 124 p. Kazan, Tatar. kit.nəshr. (In Tatar)

Al'betkova, R. I. (compiled by) (1991). Aktivnye formy prepodavaniia literatury: Lektsii $i$ seminary na urokakh $v$ st. klassakh [Active Forms of Teaching Literature: Lectures and Seminars in Senior Classes]. 174 p. Moscow, Prosveshchenie. (In Russian)
Arkhiv Zlatoustovskogo gorodskogo okruga [Archive of the Zlatoust City District (AZGO)]. Sbornik Postanovlenii Zlatoustovskogo uezdnogo sobraniia (SPZUS). Razdel "Obrazovanie" za 1894. (In Russian)

Isanbet, N. (1999). Bebi chak (Isteleklerden) [Childhood (From Memoirs)]. Miras. No. 1, pp. 91-101. (In Tatar)

Isanbet, N. (1999). Bebi chak (Isteleklerden) [Childhood (From Memoirs)]. Miras. No. 12, pp. 95104. (In Tatar)

Isanbet, N. (1974). Bereze Pesie Myraubai batyr maiaralary ham bashkalar [The Adventures of Myraubai Batyr, the Cat from the Village of Bereze and Other Stories]. 208 p. Kazan, Tat. kit. nəshr. (In Tatar)

Isanbet, N. (2010). Tatar halyk makallare [Tatar Folk Proverbs]. V 3 tomakh. T. 1. 622 p. Kazan, Tatar. kit. nəshr. (In Tatar)

Isanbet, N. (1970). Tatar halyk tabyshmaklary [Tatar Folk Riddles]. 568 p. Kazan, Tat. kit. neshr. (In Tatar)

Isanbet, N. (1968). Unsigezenche eldan ber sakhifo [One Page of Life from the Year of 1918]. Sovet edebiiaty, No. 4, pp. 95-109. (In Tatar)

Isənbət, N. (1989). Eserler: 4 tomda [Works in Four Volumes]. 1 t. 310 p. Kazan, Tatar. kit. neshr. (In Tatar)

Khabutdinov, A. Iu., Khabutdinova, M. M. (2019). Obraz Naki Isanbeta $v$ tatarskoi proze [The Image of Naki Isanbet in Tatar Prose]. Filologiia i kul'tura. Philology and Culture. No. 4, pp. 191-204. (In Russian)

Khabutdinova, M. M. (2020). Povsednevnaia zhizn' shakirdov tatarskikh medrese $v$ nachale XX veka $v$ vospominaniiakh Naki Isanbeta [Daily Lives of Tatar Madrasah Shakirds in the Early $20^{\text {th }}$ Century (based on Naki Isanbet's Memories). Tatarica. No. 14, pp. 78102. (In Russian)

Khabetdinova, M. M. (2020). "Chorlar rukhanie" ["The Spiritual Leader of Epochs"]. Kazan utlary, No.1, pp. 150-162. (In Tatar)

Khanzafarov, N. (1982). Naki Isanbet dramaturgiiase [Naki Isanbet's Dramaturgy]. 192 p. Kazan, Tatar. kit. nashr. (In Tatar)

Marantsman, V. G. (1965). Biografiia pisatelia v sisteme esteticheskogo vospitaniia shkol'nikov: Posobie dlia uchitelia. [Biography of the Writer in the System of Aesthetic Education of Schoolchildren: A Guidebook for Teachers]. 75 p. Moscow; Leningrad, Prosveshchenie. (In Russian)

Natsional'nyi arkhiv Respubliki Bashkortostan [National Archive of the Republic of Bashkortostan]. Fond I-10, Inventar 1, Case 1495. (In Russian)

Natsional'nyi arkhiv Respubliki Bashkortostan [National Archive of the Republic of Bashkortostan]. Fond I-295, Inventar 4, Case 334. (In Russian)

Natsional'nyi arkhiv Respubliki Bashkortostan [National Archive of the Republic of Bashkortostan]. Fond I-295, Inventar 11, Case 743. (In Russian)

Natsional'nyi arkhiv Respubliki Bashkortostan [National Archive of the Republic of Bashkortostan]. Arkhiv No. 546. (In Russian) 
Natsional'nyi arkhiv Respubliki Bashkortostan [National Archive of the Republic of Bashkortostan]. Arkhiv No. 1479. (In Russian)

Pallas, P. S. (1786). Puteshestvie po raznym mestam Rossiiskogo gosudarstva. Chast' 2. Kn. 1. Fizicheskoe puteshestvie po raznym provintsiiam Rossiiskoi Imperii, byvshee $v 1770 \mathrm{~g}$. [Travel to Different Places of the Russian State. Part 2. Book 1. Physical Journey through Different Provinces of the Russian Empire, which was in 1770]. Per. s nem. F. O. Tumanskogo. 476 p. St. Petersburg, Imp. Akademiia nauk. (In Russian)

Shamukov, G. (1959). Naki Isanbet [Naki Isanbet]. 76 p. Kazan, Tatar. kit.neshr. (In Tatar)
Zinurov, G. N. (2010). Imamy sela Lakly [Imams of Lakly Village]. (Seriia: Propovedniki islama. Kniga 2). 110 p. Ufa, Vostochnaia pechat'. (In Russian)

Zinurov, G. N. (2004). Istoriia sela Lakly Salavatskogo raiona Respubliki Bashkortostan [The History of Lakly Village in the Salavat District of the Republic of Bashkortostan]. 436 p. Ufa, RIO BashGU. (In Russian)

Zinurov, G. N. (2015). Tropoi sud'by: Dokumental'naia povest' [The Path of Fate: A Documentary Novel]. 334 p. Ufa. (In Russian)

\title{
НЕИЗВЕСТНЫЕ СТРАНИЦЫ В БИОГРАФИИ НАКИ ИСАНБЕТА
}

\author{
Гранит Нуруллович Зинуров, \\ Россия, 450000, Уфа, ул. К.Маркса, д. 37, корп.1, оф.206, \\ abzalimovarg@mail.ru.
}

\begin{abstract}
В статье ликвидируются «белые пятна» в биографии известного татарского писателя, фольклориста, ученого-энциклопедиста Наки Исанбета (1899-1992), родившегося в Башкортостане. Материалом исследования послужили краеведческие, архивные материалы, произведения писателя, фольклорные материалы ученого. Цель научной работы - выявить значение краеведческих материалов о деревне Лаклы для раскрытия особенностей жизненной позиции Наки Исанбета.
\end{abstract}

Ключевые слова: татарская литература, татары, история Башкортостан, Лаклы, мулла.

\section{Введение}

Изучение жизненного пути писателя относится к числу тех проблем, которые всегда вызывали живой интерес у литературоведов, педагогов, краеведов. Это закономерно, потому что, как верно подметил методист В. Г. Маранцман, «жизнь художника не менее волнующее и поучительное явление, чем судьба созданных им героев» [Маранцман, С. 38]. По мнению Е. Н. Колокольцева, биография художника слова является не набором отдельных, изолированных фактов его жизни и творчества. Биография - это «о л и е т в о рен но е в ре мя», «духовная эволюция писателя и материальное ее выражение возникновение творческих стимулов на различных витках жизни» [Активные формы преподавания литературы, с. 54]. Общеизвестно, что изучение биографии писателя является необходимым условием постижения его художественного мира.

В биографии великого писателя-энциклопедиста Наки Исанбета (1899-1992) немало «белых пятен». К сожалению, в монографиях и биографических статьях о великом ученом уделяется недостаточно внимания изучению баш- кирской страницы его жизни ([Шамуков], [Ханзафаров], [Әдип һәм галим], [Хабутдинов, Хабутдинова], [Хәбетдинова], [Хабутдинова]). Цель нашей статьи - углубить представление широкого круга читателей о родословной Н. Исанбета, о лаклинской странице его жизненного пути. Материалом для исследования послужили краеведческие материалы и произведения самого писателя.

\section{Методы}

При рассмотрении художественных текстов мы использовали метод смыслового анализа, а также историко-культурный метод.

\section{Обсуждение}

Деревня Лаклы находится на северовосточной окраине Республики Башкортостан. Среди местных жителей бытуют разные версии происхождения названия этого села в Салаватском районе: «лаклы», «улак». У тюркоязычных народов этими словами обозначают созвездие Козерога. Местные жители говорят о стадах диких коз, которые раньше обитали в горных окрестностях села. Возможно, название 
деревни связано с этими обстоятельствами. Известно, что в Лаклах побывал немецкий ученый-энциклопедист, естествоиспытатель и путешественник на русской службе в 1767-1810 гг. Петр Симон Паллас. Случилось это 25 мая 1770 г. (через 10 лет после переселения на эти земли): «Поехал для осмотру достопамятной пещеры, влево три версты с дороги к татарской деревушке Цигярцинкуль. Жители оныя по прежде бывшему в сей стране общему обычаю отдают в казну старый ясак или подать куньими мехами по той цене. Деревня сия в немногих дворах лежит при ручье Лякле Зилге, который первый в реку Ай впадает и при котором кончится плодоносная равнина, заключающая в себе Залихауль (т. е. Насибаш)» [Паллас, с. 68]. Возможно, свое название деревня получила от названия ручья - Лякле Зилге.

Известный татарский писатель-энциклопедист Наки Исанбет (1899-1992) в своих трудах использует название Ылаклы. Название деревни встречается в сборниках загадок и пословиц, составителем которых выступает фольклорист. В сборнике «Татар халык табышмаклар» («Татарские народные загадки») приводится несколько загадок, записанных в нашей родовой деревне. Вот, например, загадка о воде:

\begin{tabular}{|l|l|}
\hline «Үзе тигез, Үзе такыр, & «Сама гладкая, сама \\
Бассаң - батар. & ровная, \\
Исе юк, төсе юк, & Наступишь - утонешь. \\
Аннан башка тормыш & Запаха нет, бесцветная, \\
юк» & Без нее жизнь \\
[Исәнбәт, 1970, с. 116]. & невозможна» \\
& (здесь и далее \\
& постр. пер. наш. - Г. 3.). \\
\hline
\end{tabular}

Загадка о коровьем роге:

\begin{tabular}{|l|l|}
\hline «Коры ботакка кайгыр & «Маленький, юркий \\
кунмас.. » [Там же, с. & ястреб не сядет на сухую \\
$225]$. & ветку». \\
\hline
\end{tabular}

В сборнике «Татар халык мәкальләре» («Татарские народные пословицы») мы обнаружили ряд пословиц, записанных в нашей деревне: «Юньсез итеген майлар, / Итеге итәген майлар» («Бестолковый смажет сапоги, а сапоги смажут подол платья») [Исәнбәт, 2010, c. 231], «Исәпкә - хисап, / Килегә - кисап» («По счету - рассчет, по ступе - пест») [Там же, с. 259], «Уралның уравы күn» («На Урале много обходных путей») [Там же, с. 307], «Алтын юкта жсизне „жсиз мыек жсизни“ дип йөртерләр, имеш» («Говорят, что зятя, не имеющего золота, называют „зять с латунными усами“») [Там же, с. 310] и т. д.

Наки Исанбет - уроженец татарской деревни Малаяз в Башкортостане - упоминает деревню Ылаклы и в своих художественных произведениях, в частности в приключении, написанном для детей, «Бәрәзә песие Мыраубай батыр мажаралары» («Приключения Мыраубай батыра, кота из Березэ»). В 8-м приключении кота Мыраубая указывается, что жители ряда татарских населенных пунктов переживают о том, что слишком поздно узнали о проведении Джиена на Арском поле Казани:

\begin{tabular}{|l|l|}
\hline «Соң ишеткән бу хәбәрне & «Поздно узнали об этом \\
Колаткылар, & известии жители Колат- \\
Алабуга, Богадышлар, & кы, \\
Ылаклылар, & Елабуги, Богадыша, Лак- \\
Атау, Кыйгы, Яңа & лы, \\
Мөслим, Өлкенделәр: & Атау, Киги, Новое Мус- \\
- Ах, ник алдан & люмово, Улькинди: \\
белмәдек! - дип & - Ах, почему мы об этом \\
үкенделәр» & не знали! - горевали \\
[Исәнбәт, 1974, б. 64]. & они». \\
\hline
\end{tabular}

В авторских примечаниях Наки Исанбет так объясняет феномен этих деревень: «Ылаклы, Атау, Кыйгы, Яңа Мөслим, Өлкендә Башкортостан Салават районындагы зур татар авыллары. Болардан зур галимнәр, шагыйрьләр дә чыкканнар» [Исәнбәт, Бәрәзә песие..., с. 64]. - «Лаклы, Атау, Киги, Новое Муслюмово, Улькинди - это большие татарские деревни в Салаватском районе Башкортостана. Отсюда вышли известные ученые, а также поэты».

Комментарий Н. Исанбета соответствует истине. Если обратиться к архивным документам, то можно выяснить, что село Лаклы Салаватского района Республики Башкортостан возникло в середине XVIII века согласно договору от 3 февраля 1760 года с вотчинниками Тарнаклинской волости Оренбургской губернии. Основали его семь домохозяев, которые отделились из села Таймеево и поселились на берегу реки Ай, у устья речки Лаклы. Среди первопереселенцев был мулла Сулейманов Гайса (1729-1802 гг.). С его благословения была построена первая мечеть в селе. Гайса мулла возглавлял первый лаклинский приход свыше четырех десятилетий. Согласно семейным преданиям, Гайса, как и его отец, получил духовное образование в Бахчисарае. Позднее, в 1798 году, управление Лаклинским приходом перешло в руки его старшего сына Худайбирде (1768-1847) (Указ Уфимского губернского 
правления № 12623 от 3 мая 1811 г.). Вместе с ним должность азанчы получил Исиядулла Сейфуллин. В Указе отмечается, что Худайбирде (Г) Айсин был родом из типтярей.

Для нас сенсационным открытием стал тот факт, что существовал договор о переселении лаклинцев из деревни Таймеево в 1760 году. Если перевести этот документ, написанный на татарском языке на арабской графике на русский, то он гласит:

«Это историческое решение, написанное на татарском языке с согласием тысяча семьсот шестидесятом году в начале месяца Шаваль (февраль. $-\Gamma$. 3.) третьего дня дали:

Мы, Уфимского уезда, Сибирской дороги, Тарнаклинского войска (волости) люди, старшие и молодые с общего согласия, отданную нам Указом Милосердного Падишаха Великого хазрета (Е И В) землю, уступили этого же Уфимского уезда, Сибирской дороги деревне Атав ясачным татарам: Ягуде сыну Алки, его старшему брату мулле Халилу-сыну Алки, мулле Гайсе-сыну Сулеймана, Исмагилу-сыну Саита, Ибраю-сыну Нурки, сотнику Максуту-сыну Габдуллы, Гумеру-сыну Утегана с подходящими себе спутниками десяти домовладельцам от хозяина к хозяину с уплатой по двадцати пяти копеек сын сыну, кровь крови навечно посвящает. Если от отца сын отделится, если от старшего брата младший брат отделится и домов будет больше, чем указана выше, решили так же брать по двадцати пяти копеек со двора» [НА РБ, ф. И-10, оп. 1, д. 1495, л. 9].

По этому договору лаклинцам из Таймеево отводилось около 6000 десятин земли.

В архивных материалах указывается, что в Лаклах была простая мечеть, которая из-за недостатка прихожан функционировала только по пятницам. По законам того времени для организации соборной мечети было необходимо минимум 200 прихожан мужского пола, а в Лаклах, по ревизии 1811-1812 года, было не более 88 душ мужского пола. Лаклинцы мечтали построить большую красивую соборную мечеть. Худайбирде был человеком решительного нрава. Под предлогом, что ветхая мечеть пришла в негодность, в 1814 году вместе со своими родственниками он разобрал ее и 14 лет занимался строительством нового здания. Тяжба вокруг новой мечети растянулась до 1823 года, так как строительные работы велись без получения разрешения у губернских властей и Оренбургского Магометанского Духовного Собрания (ОМДС) [НА РБ. ф. И-295, оп. 4, д. 334].

Согласно Указу Уфимского губернского правления № 5153 от 23 февраля 1833 года вторым имамом и мугаллимом в новой соборной мечети был назначен внук Гайсы хазрета - Багаутдин, автор рукописной книги «Китаби Багаутдин валяды Шамсивар» (1829). Он возглавлял приход на протяжении пяти десятилетий. Известно, что, благодаря его руководству, лаклинское медресе вскоре обрело популярность. В 1858 г. Багаутдин хазрет взялся за капитальный ремонт мечети. В 1862 г. он передал свои родовые земли и участок леса в собственность мечети. Граница лесного массива проходила от Урманчинской дороги по линии погоста до дороги «Наискосок» на горе Хутор-тау и вглубь. Этот лесной массив до настоящего времени носит название «Мәчет саклауы» («На сохраненении мечети»). Багаутдин хазрет отпустил на волю своих крестьян. По воспоминаниям старожилов, на поляне перед лесом лаклинская молодежь собиралась на посиделки, а при совесткой власти, в 1960-е гг., на месте, связанном с памятью о религиозных деятелях-просветителях, появилась свиноферма.

После смерти Багаутдина хазрета местную мусульманскую общину возглавил его сын Ахмедсафа (ибн Багаутдин ибн Шамсивар ибн Гайса ибн Сулейман... ибн Сююндюк...). Это был известный татарский религиозный и общественный деятель, учитель, преподаватель, просветитель, мударрис медресе «Ахмадия». Ахметсафа Багаутдин был лидером мусульман Златоустовского уезда Уфимской губернии. Первичное образование он получил в медресе своего отца. Ахметсафа очень рано проявил свои незаурядные способности к образованию. К 14 годам снискал славу знающего Коран наизусть (Коран-хафиз) и показал глубокие познания коранических наук и мусульманского права - шариата. В 1875-1881 годы Ахметсафа Багаутдин учился в медресе первой мечети города Троицка, а летом обучал казахских детей грамоте. После успешного окончания медресе два года служил на Сибирской линии писарем и толмачем-переводчиком. После избрания муллой лаклинским приходом в 1883 (19 января, протокол № 2687) году по рекомендации Багаутдина хазрета Ахметсафа совершил хадж, в течение года посещал святые места, приобретал книги, встречался с известными богословами Востока и получил их благословение. Известно, что Ахметсафа совершил хадж дважды. В 1884 году он получил указ Уфимского губернского правления № 672 от 10 февраля на Лаклинский приход имам-джамихом (имамом Соборной мечети), хатибом и мударрисом вместо своего отца. 
Ахметсафа Багаутдин взял бразды правления над лаклинским медресе в 1884 году, в один год с Зайнуллой Расулевым, возглавившим медресе «Расулия» при 5-м приходе города Троицка. Известно о многократных посещениях лаклинского медресе ишаном Зайнуллой. Муллы-просветители взаимно корректировали программы обучения в своих медресе.

Ахмедсафа ахун был попечителем и мударрисом (директором) лаклинской медресе «Ахмадия», названной его именем, и учителем лаклинской русско-татарской школы. Он активно участвовал в открытии в Лаклах мужской русско-татарской (1894) и женской русскотатарской (1905) школ. Ахметсафа хазрет в русско-татарской школе преподавал родной язык и вероучение. В документе по поводу открытия школы читаем: «Открытие в деревне Лаклы русско-татарского училища, куда сразу поступили 27 учеников, дает возможность обучаться русской грамоте, находящихся до открытия (училища) исключительно под влиянием магометанского медресе, где обучаются ежегодно более 200 детей мусульманского населения Златоустовского уезда» [Архив Златоустовского городского округа (АЗГО). Сборник Постановлений Златоустовского уездного собрания (СПЗУС). Раздел «Образование» за 1894]. Следовательно, уже в 1894 году в лаклинском медресе обучалось до 200 детей.

Если в мектебе изучали арифметику, географию, астрономию, рахбари-сабиян 1-3 части, Коран, афтияк, Мугаллими гибадати 1-3 части, Гильмихал, Гибадати исламия на арабском и татарском языках, то в русско-татарской школе все предметы, кроме родного языка и коранических дисциплин, стали преподаваться на русском языке.

В связи с ходатайством Ахмедсафы ходжи хазрета и населения, уездное Земское Собрание постановило изучить постановку учебного процесса в Лаклах. Изучая цели и задачи мусульманских учебных заведений, Златоустовская уездная земская управа пришла к выводу, что «магометанское учебное заведение-медресе преследует общеобразовательные и духовнонравственные цели. Цель обучения в этих школах одна и та же - сделать учащегося грамотным гражданином, полезным для общества и государства, человеком истинным и образованным» [НА РБ, архивный № 1479, с. 597]. По вопросу о том, какой район мусульманских селений обслуживает Лаклинское медресе, говорится, что «лаклинское медресе обслуживает все мусульманское население Златоустовского уезда» [НА РБ, архивный № 546, с. 426].

Выступая с отчетным докладом в 1906 году, Управляющий народным образованием Златоустовского уезда очень высоко оценил деятельность известного муллы-просветителя: «Благодаря горячему участию местного муллы Багаутдинова в деле как открытия школы в этой деревне, так и привлечения учащихся в данную школу, на первый же год ее открытия поступили 30 девочек, что представляет громадный успех, так как магометанское население относится с большой неохотой к обучению русской грамоте своих детей вообще, а девочек в особенности. Отмечая такое сочувственное отношение муллы Багаутдинова к народному образованию магометанского населения, Управа полагала бы о таком усердии Багаутдинова довести до сведения муфтия» [НА РБ. Ф. И-295, оп. 11, д. 743, стр. 125].

Приводим текст письма Златоустовской уездной земской управы Уфимскому Муфтию целиком:

«Златоустовская уездная земская управа

Ноября 16 дня 1906 года № 3538.

Его Высокостепенству Господину Уфимскому Муфтию.

С начала 1905-906 учебного года в деревне Лаклах Тарнаклинской волости Златоустовского уезда открыто земское женское русско-татарское начальное училище. Ввиду того, что башкирское население крайне недоверчиво относится к открытию вообще среди оного училищ для обучения русской грамоте, а женских школ в особенности, Уездной управе пришлось принимать очень энергичные убеждения к принятию лаклинцами названного училища. Причем деятельное участие к убеждению их принимал местный мулла Багаутдинов, он же вероучитель земского мужского начального училища, сердечно и энергично относившийся и к привлечению в школу башкирских девочек. Благодаря такому горячему участию Багаутдинова в деле просвещения русской грамотой детей школьного возраста деревне Лаклов в первый же год поступило во вновь открытое женское лаклинское училище 30 учащихся. Златоустовское Уездное Земское собрание XXII очередной сессии 1906 года по выслушании такого лестного отзыва Уездной Управы о проявленном муллой Багаутдиновым горячем участии в деле распространения народного образования среди башкирского населения, уполномочило (постановление от 5 октября 1906 г.) Уездной Управе выразить от лица Земского Собрания искреннюю признательность мулле Багаутдинову. Вместе с тем предложило Управе о такой продуктивной деятельности г(осподина) Багаутдинова довести до сведения Господина Муфтия. 
О чем Уездная Управа считает приятным своим долгом довести до сведения Вашего Высокостепенства.

Председатель Управы Аистов» [НА РБ. Ф. И295 , оп. 11 , д. 743 , с. 125$]$.

Ахметсафа Багаутдин активно стремился приобщить свой народ к просвещению и культуре. Для этого прикладывал все свои возможности и усилия. Благодаря его активной позиции в вопросах модернизации образования, Лаклы на рубеже XIX-XX вв. становится центром прогрессивной образованности на северо-востоке Уфимской губернии, и ОМДС возложило на него обязанность с инспекцией объезжать все мектебы и медресе Златоустовского уезда. В одну из таких поездок Ахметсафа Багаутдин заехал в Малаяз к Сиразетдину мулле и провел обряд имянаречения его сыну Ахметнаки.

Из воспоминаний Нигматуллы Зайнуллина мы узнали о том, что преподавали в медресе городские учителя Махмуд Султангалиев с супругой Суфией, Халима Байтирякова и другие. После окончания Оренбургского медресе вернулся в Лаклы Галимьян Сафин. Известно, что в лаклинском медресе учились шакирды из Троицка, Уфы, до этого обучавшиеся в медресе «Галия», «Хусаиния» и других. В медресе преподавали татарский язык, географию, историю, математику. Три раза в неделю были уроки вероучения. Программа обучения в медресе соответствовала программе 7 класса современной школы. По-видимому, в сельскую глубинку шакирдов загнали бурные революционные события.

Бытовые условия для шакирдов медресе «Ахмадия» значительно улучшились после строительства нового здания медресе в 1908 году. Здесь обучалось под руководством 9 мугаллимов свыше 200 человек. В медресе преподавал старший сын Ахметсафы Багаутдина Галимьян - выпускник Оренбургского медресе «Хусаиния». Позднее он возглавил школу на станции Мурсалимкино (Башкортостан).

В 1907 году Ахметсафа Багаутдин был назначен ахуном Златоустовского уезда. Ему удалось найти общий язык с органами местного самоправления. Так, мулла-просветитель получил от земства пособие на постройку учебного заведения в родном селе. На заседании Златоустовского уездного земского собрания «Гласный (депутат) Щипицин» [НА РБ, архивный № 1479, с. 597] просил удовлетворить ходатайство муллы на постройку здания медресе, так как Лаклы является «рассадником (источником) культуры среди мусульманского населения» [НА РБ, архивный № 1479, с. 597]. Это, безусловно, показывает, что Ахмедсафа хазрет имел огромный авторитет не только среди мусульманского населения, но и перед Российской властью в лице Златоустовской земской управы благодаря своей активной просветительской и общественной деятельности. Супруги Ахмедсафы - Тайба абыстай и Галима абыстай - также принимали активное участие в жизни села. Они обучали девочек грамоте, женской гигиене. Тайба абыстай была повивальной сестрой и принимала роды.

Ахмедсафа ахун в 1927 году был арестован, отсидел несколько месяцев в Месягутовской тюрьме. Большевики были вынуждены выпустить ахуна на свободу во избежание бунта на территории Златоустовского округа Уральской области и Месягутовского кантона Башкирской республики (БАССР). Когда мулла оказался в тюрьме, в Месягутово стали стекаться с семьями его многочисленные ученики-шакирды, земляки-мусульмане. Люди проходили сотни километров, чтобы поддержать уважаемого человека и учителя. Улицы села Месягутово были заполнены пешими, верховыми людьми, подводами с семьями. Вокруг тюрьмы стояли километровые очереди, люди неделями ждали свидания с ним, чтобы получить его благословение. Авторитет и популярность Ахмедсафы ходжи хазрета были огромны. Он был святым человеком в глазах простого народа. Как и его предки, Ахмедсафа обладал даром ясновидения, врачевания, психотерапии. Ахметсафа Багаутдин так и не оправился после ареста, начал болеть и умер в 1929 году в своем доме. Наградой за просветительскую деятельность от властей стали тюрьма и раскулачивание, а в народе - общенародное уважение и признание заслуг.

Ахмедсафа жил весьма скромно. В его хозяйстве были телега, тарантас на железном ходу -1 , рабочих лошадей - 2 , выездная лошадь 1 , коров -3 , телят -2 , купленная земля - 15 десятин. Земельного надела не имел, так как родился после переписи 1859 года, поэтому в список ревизских душ не попал. Посев: овес - 3 десятины, яровой пшеницы - 1,5 десятины, картошки 5 соток. Остальные земли отдавал в аренду. Сам брал в аренду сенокосные угодья с договором на 12 лет. Он имел от разных жен 6 детей.

Усадьба Ахмедсафы представляла собой березовую рощу размером 0,9 десятин, примерно один гектар, тянущуюся с востока на за- 
пад. С восточной стороны располагался дом с парадным выходом на улицу. В середине рощи стояло небольшое восьмигранное здание, которое одновременно служило библиотекой, кабинетом, местом молебен Ахмедсафы. Библиотека была собрана предками Ахмедсафы и самим хазретом. Здание библиотеки восточной архитектуры, расположенное в тихой березовой роще его усадьбы, олицетворяло восьмигранную звезду. Ахмедсафа, видимо, знал, что восьмигранные символы и звезды очень благотворно действуют на человеческое общество и на общее состояние человека. Все свободное время он проводил, уединившись в своей любимой библиотеке: занимался науками, молился, медитировал, искал истину. В этой библиотеке хранились не только религиозные книги, но и произведения русских классиков. В 1929 году эта библиотека была утрачена. Ахмедсафа хазрет не успел передать библиотеку в государственное пользование из-за безвременной смерти во время разгула раскулачивания.

В советские годы мысль о «богатстве» Ахмедсафы Багаутдинова лишила некоторых односельчан покоя. Им казалось, что, работая 46 лет имамом большого лаклинского прихода, учителем и мударрисом медресе, инспектором мусульманского народного образования целого уезда, занимаясь даже торговлей (сын Ахмедхадый), он должен был накопить большое состояние. Никто не мог поверить, что состояние этого известного в округе просветителя состояло из небольшого дома из двух комнат и кухни.

С целью обнаружения клада его дом перенесли на 70 шагов в сторону. Естественно, никакого клада никто не нашел, так как клад и вклад Ахмедсафы Багаутдина измерялся медресе «Ахмадия», его духовным вкладом в образование своего народа.

Первая соборная мечеть в Лаклах, таким образом, была построена в 1828 году, Вторая соборная мечеть - в 1900 году. В 1929 году после смерти ахуна мечеть была передана Школе крестьянской молодежи. Мечеть служила школой до 1970 года, после чего было построено новое здание советской школы.

В 1931 году дом Ахмедсафы Багаутдина изъяли в пользу «народа» и превратили в здание сельского совета. Сына Ахмедсафы Васила в возрасте 21 года осудили как контрреволюционера по статье 58 пункт 10 Уголовного Кодекса РСФСР за связь с чуждым элементом, то есть с отцом. Отбыв свой срок, после освобождения в годы Великой Отечественной войны он ушел на фронт. Младший сын Ахмедсафы Багаутдина по имени Мухаммед также был участником войны. Он долго скитался по госпиталям, пытаясь встать на ноги после тяжелой контузии. Известно, что он умер в городе Челябинске.

Березовую рощу размером в 1 гектар на усадьбе ахуна и в 1 гектар возле мечети односельчане Ахметсафы вырубили на дрова во время Великой Отечественной войны. К сожалению, до сих пор роща, украшавшая центр села, не восстановлена.

Во время беседы бывший секретарь Салаватского райкома КПСС Радил Мухаметдинов, который руководил районом в течение семнадцати лет, отмечал, что самыми работящими, культурными, образованными в Салаватском районе были выходцы из Лаклов. Выпускники Лаклинского медресе в будущем стали министрами, генералами, учеными, инженерами, врачами, учителями, директорами школ, партийными и хозяйственными работниками. Медресе «Ахмадия» сыграло значительную роль в культурном и образовательном развитии мусульманского населения Златоустовского уезда и всего северо-востока Уфимской губернии (см. подр.: [Зиннуров, 2004], [Зиннуров, 2010], [Зиннуров, 2015]).

В автобиографической повести Наки Исанбета «Бәби чак» («Детство») мы обнаружили ценные сведения о родословной великого писателя. Н. Исанбет в своем произведении указывает, что в Лаклах жили его родственники по материнской линии ([Исәнбәт, 1999], [Исәнбәт, 2000]). Это была родовая деревня его бабушки Хадичи Багаутдиновой, родной сестры Ахметсафы хазрата:

«Сиражетдин белән Таибәдән мин дөньяга килгәнмен. Ягъни Нисебашның, Әхмәтша мәэззин анам ягыннан. Минем карт атай, аның карчыгы Хәдичә минем карт инәй булалар. Малаяз исә татар авылы, Нисебашныкылар мишәрләр, ә Хәдичә карт инәй Лаклы авылыннан, алар исә татарлар» [Исәнбәт, 1999, с. 98]. - «Я родился в семье Сиразетдина и Таибы. То есть Насибашевские были родственниками по линии матери, со стороны Ахметши муадзина. Малаяз была татарской деревней, Насибаш - мишарской, а бабушка Хадича была родом из Лаклы, они были из татар».

Образ Лаклы встречается также в мемуарной статье Н. Исанбета «Унсигезенче елдан бер сәхифә» («Страница жизни из восемнадцатого года», 1967). Описывая трагические события во 
время вилочного восстания, писатель называет имена героев-революционеров, погибших от враждебных рук: в частности, таких известных жителей Лаклы, как Хамматовы [Исәнбәт, 1968, c. 106].

Н. Исанбет не раз бывал в Лаклах. В юности он брал уроки у Ахметсафы Багаутдина.

\section{Результаты}

Лаклы для Наки Исабета является деревней родиной его предков по материнской линии, центром образованности на северо-востоке Башкортостана, а также местом для сбора интересного и самобытного фольклорного материала.

\section{Выводы}

Лаклинская страница в биографии Наки Исанбета позволяет нам глубже понять мировоззрение ученого-просветителя. Предки писателя на протяжении нескольких столетий являлись подвижниками-проводниками знаний и мусульманской культуры в регионе. Очевидно, что бессмертные строки из пьесы Н. Исанбета «Абугалисина» являются жизненным кредо не только писателя, но и целого рода татарских мулл-просветителей:

\begin{tabular}{|l|l|}
\hline «Аһ, юк, мин ни өчен & «Ах, зачем я обрел \\
гыйлем алдым, & знания, \\
тимәгәч? & Если они не на пользу \\
Кояш булып кояш кемгә & моего народа? \\
хажәт, & Кому нужно солнце, \\
Башкаларга нурын & Если оно не согревает \\
бирмәгәч? & лучами других? \\
Юк, юк! Алар бәхте - & Нет, нет! Их счастье - \\
минем бәхтем, & мое счастье, \\
Телим - халкым күзе & Хочу - чтобы мой народ \\
ачылсын, & прозрел, \\
Гыйлем белән алар көчле & Он обретет силу, \\
булсын. & благодаря знаниям. \\
Сөю, хаклык жирдә шаһ & любовь, справедливость! \\
булсын! & Тогда он осознает свое \\
Алар аңлар шунда үз & положение, \\
хәлләрен, & Никто ни для кого не \\
Артык кеше кешегә кол & будет рабом, \\
булмас, & Ни один народ не \\
Бер халыкны берсе & обретет на рабство \\
табындырмас, & другие народы, \\
Сәждә булмас, һичкем & Не будет, возвышаясь \\
зур булмас» [Исәнбәт, & над другими, ставить \\
1989, с. 236]. & никого на колени». \\
\hline
\end{tabular}

\section{Литература}

Активные формы преподавания литературы: Лекции и семинары на уроках в ст. классах / сост. Р. И. Альбеткова. М.: Просвещение, 1991. 174 с.
Зинуров Г. Н. Тропой судьбы: Документальная повесть. Уфа, 2015. 334 с.

Зинуров Г. Н. История села Лаклы Салаватского района Республики Башкортостан. Уфа: РИО БашГУ, 2004. 436 с.

Зинуров Г. Н. Имамы села Лаклы. (Серия: Проповедники ислама. Книга 2). Уфа: Восточная печать, 2010. $110 \mathrm{c}$.

Мараниман В. Г. Биография писателя в системе эстетического воспитания школьников: Пособие для учителя. Москва; Ленинград: Просвещение, 1965. $75 \mathrm{c}$.

Паллас П. С. Путешествие по разным местам Российского государства. Часть 2. Кн. 1. Физическое путешествие по разным провинциям Российской Империи, бывшее в 1770 г. / пер. с нем. Ф. О. Туманского. СПб.: Имп. Академия наук, 1786. 476 с.

Хабутдинов А. Ю., Хабутдинова М. М. Образ Наки Исанбета в татарской прозе // Филология и культура. Philology and Culture. 2019. № 4. С. 191204.

Хабутдинова M. M. Повседневная жизнь шакирдов татарских медресе в начале XX века в воспоминаниях Наки Исанбета. Tatarica. 2020. № 14. C. $78-102$. 124 б

Әдип һәм галим. Казан: Тат. кит. нәшр., 1969.

Исәнбәт Н. Әсәрләр 4 т. Т. 1. Казан: Татар. кит. нәшр., 1989. 312 б.

Исәнбәт Н. Бәби чак // Мирас. 1999. № 1. Б. 91101.

Исәнбәт Н. Бәби чак // Мирас. 2000. № 1. Б. 95104.

Исәнбәт H. Бәрәзә песие Мараубай батыр мажаралары һәм башкалар. Казан: Тат. кит. нәшр., 1974. $208 \mathrm{c}$.

Исәнбәт H. Татар халык мәкальләре: 3 т. Т. 1. Казан: Татар. кит. нәшр., 2010. 622 б.

Исәнбәт H. Татар халык табышмаклары. Казан: Тат. кит. нәшр., 1970. 568 б.

Исәнбәт Н. Унсигезенче елдан бер сәхифә // Совет әдәбияты, 1968, № 4. Б. 95-109.

Хәбетдинова М. М. «Чорлар рухание» // Казан утлары, 2020, № 1. Б. 150-162.

Ханзафаров H. драматургиясе. Казан: Татар. кит. нәшр., 1982. 190 с.

Шамуков Г. Нәкый Исәнбәт. Казан: Тат. кит. нәшр., $1959.76 \mathrm{c}$.

Архив Златоустовского городского округа Сборник Постановлений Златоустовского уездного собрания (СПЗУС). Раздел “Образование” за 1894.

Национальный архив Республики Башкортостан (НА РБ), Ф.И-10, оп. 1, д. 1495 , л. 9.

НА РБ. Ф.и-295, оп. 11, д. 743, с. 125.

НА РБ. Ф.и-295, оп. 4, д. 334.

НА РБ, архивный № 1479.

НА РБ, архивный № 546. 


\title{
НӘКЫЙ ИСӘНБӘТНЕН ТОРМЫШЫ ЮЛЫНДА БИЛГЕСЕЗ СӘХИФӘЛӘР
}

Гранит Нурулла улы Зинуров, Россия, 450000, Уфа ш., К. Маркс ур., 37 нче йорт, корп.1, оф.206, abzalimovarg@mail.ru.

\begin{abstract}
Мәкаләдә Башкорстанда туып үскән күренекле татар язучысы, фольклорчы, галимэнциклопедист Нәкый Исәнбәт (1899-1992) тормышында булган “ак таплар” ачыклана. Төбәк тарихына караган төрле архив материаллары, чыганаклар, язучының әдәби һәм фольклор текстлары өйрәнелә. Фәнни эшнең максаты - Нәкый Исәнбәтнең дөньяга карашларының үзенчәлекләрен аңлау максатыннан, Лаклы авылы тарихын ача торган материалларның әһәмиятен билгеләү.
\end{abstract}

Төп төшенчәләр: татар әдәбияты, татарлар, Башкортстан тарихы, Лаклы, мулла. 